\title{
JARGON DILIHAT DARI SISI KEKAYAAN INTELEKTUAL
}

\section{Oleh : ALI MARWAN HSB*}

Lagu "Lagi Syantik" ciptaan Yogi RPH yang dinyanyikan oleh Siti Badriah mendapat perhatian yang luas dari masyarakat Indonesia, bahkan lagu tersebut sudah diputar sebanyak lebih dari 200 juta kali di youtube. Tetapi, di samping itu, lagu ini juga mendapat sorotan dari artis Syahrini dan manajemennya yang menganggap bahwa kata-kata "syantik" tersebut diciplak dari jargon yang dipopulerkan oleh Syahrini. Selain itu, Syahrini dan manajemennya meminta agar semua pihak yang menggunakan jargon-jargon tersebut untuk mengakui bahwa jargon tersebut adalah dari ucapan Syahrini.

\section{Hal tersebut tentunya} menimbulkan pro dan kontra di kalangan masyarakat Indonesia terutama kalangan artis. Ada yang mendukung Syahrini dan tidak kalah banyak juga yang membela Siti Badriah dan Yogi RPH sebagai penyanyi dan pencipta lagu. Terlepas dari pro dan kontra yang timbul, tentu perlu dilihat bagaimana sebenarnya keberadaan jargon dari sisi kekayaan intelektual dan perlindungannya.

\section{Pengertian}

Apabila diberikan secara defenisi, kekayaan intelektual itu berarti hasil olah pikir otak manusia yang lahir karena kemampuan intelektual manusia dan menghasilkan suatu produk yang memiliki nilai ekonomis. Inti dari pengertian kekayaan intelektual tersebut adalah menghasilkan suatu produk serta memiliki nilai ekonomis sehingga dapat diperjualbelikan.

Dalam sistem hukum Indonesia, ada 6 (enam) undang-undang kekayaan intelektual, yaitu Undang-Undang Nomor 20 Tahun 2016 tentang Merek dan Indikasi Geografis, Undang-Undang Nomor 28 Tahun 2014 tentang Hak Cipta, Undang-Undang Nomor 13 Tahun 2016 tentang Paten, Undang-Undang Nomor 26 Tahun 2000 tentang Perlindungan Varietas Tanaman, Undang-Undang Nomor 30 Tahun 2000 tentang Rahasia Dagang, UndangUndang Nomor 31 Tahun 2000 tentang Desain Industri, dan Undang-Undang Nomor 32 Tahun 2000 tentang Desain Tata Letak Sirkuit Terpadu.

Dari keenam jenis kekayaan intelektual ini, ada dua jenis perlindungannya, yaitu secara deklaratif, yaitu kekayaan intelektual akan dilidungi oleh negara apabila sudah diwujudkan dalam bentuk nyata dan diumumkan kepada khalayak luas. Kekayaan intelektuan yang dilindungi secara deklaratif adalah hak cipta. Sedangkan 


\section{KEKAYAAN INTELEKTUAL}

kekayaan intelektual lainnya dilindungi secara konstitutif yang berarti kekayaan intelektual tersebut akan dilindungi oleh negara apabila sudah didaftarkan kepada instansi berwenang.

Jika dikaitkan dengan pengertian kekayaan intelektual, maka akan sulit menempatkan jargon sebagai salah satu jenis kekayaan intelektual. Jargon dapat dikategorikan sebagai merek bahkan juga dapat termasuk ciptaan yang dilindungi dengan hak cipta-nya.

\section{Jargon sebagai Merek}

Berdasarkan ketentuan Pasal 1 angka 1 Undang-Undang Nomor 20 Tahun 2016 tentang Merek dan Indikasi Geografis disebutkan bahwa "Merek adalah tanda yang dapat ditampilkan

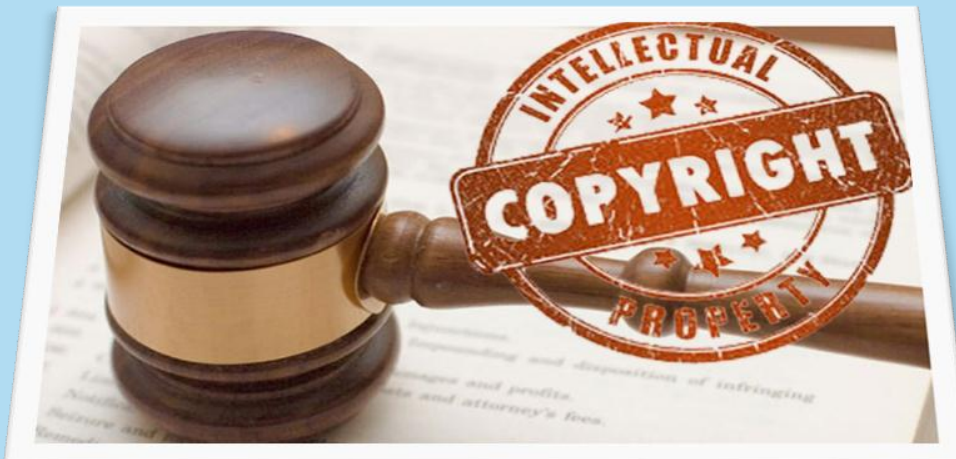

secara grafis berupa gambar, logo, nama, kata, huruf, angka, susunan warna, dalam bentuk 2 (dua) dimensi dan/atau 3 (tiga) dimensi, suara, hologram, atau kombinasi dari 2 (dua) atau lebih unsur tersebut untuk membedakan barang dan/atau jasa yang diproduksi oleh orang atau badan hukum dalam kegiatan perdagangan barang dan/atau jasa.
Dari pengertian ini dapat disimpulkan bahwa merek adalah tanda yang digunakan pada barang dan/atau jasa untuk membedakan untuk membedakan dengan barang dan/atau jasa orang lain.

Jargon termasuk sebagai merek apabila didaftarkan sebagai tanda dari suatu produk barang dan/atau jasa yang diperjualbelikan. Apabila suatu jargon sudah didaftarkan sebagai merek suatu barang dan/atau jasa, maka jargon tersebut tidak dapat lagi didaftarkan oleh pihak lain sebagai merek untuk kelas barang dan/atau jasa yang sama.

\section{Jargon sebagai Ciptaan}

Sesuai dengan ketentuan Pasal 1 angka 3 Undang-Undang Nomor 28 Tahun 2014 tentang Hak Cipta disebutkan bahwa "Ciptaan adalah setiap hasil karya cipta dibidang ilmu pengetahuan, seni, dan sastra yang dihasilkan atas inspirasi, kemampuan, pikiran, imajinasi, kecekatan, keterampilan, atau keahlian yang diekspresikan dalam bentuk nyata. Inti dari pengertian ciptaan ini adalah bahwa ciptaan adalah hasil karya dibidang ilmu pengetahuan, seni, dan sastra.

Suatu jargon dapat juga menjadi suatu ciptaan, jika diwujudkan dalam bentuk nyata di bidang ilmu pengetahuan, seni, dan sastra, seperti dibuat menjadi lagu atau puisi. Seperti lagu "Lagi Syantik" sudah menjadi salah 


\section{KEKAYAAN INTELEKTUAL}

satu ciptaan yang dilindungi oleh negara berdasarkan Undang-Undang Hak Cipta sebagai satu karya seni.

Terkait dengan merek dan hak cipta, tentu menjadi suatu pertanyaan apabila suatu jargon sudah didaftarkan menjadi suatu merek barang dan/atau jasa apakah masih bisa dilingdungi sebagai ciptaan?

Dalam Undang-Undang Hak Cipta sendiri tidak ada pengaturan mengenai hal tersebut. Hanya yang diatur adalah ada hasil karya yang tidak dilindungi hak cipta sebagaimana dinyatakan pada Pasal 41, yaitu: (a) hasil karya yang belum diwujudkan dalam bentuk nyata; (b) setiap ide, prosedur, sistem, metode, konsep, prinsip, temuan atau data walaupun telah diungkapkan, dinyatakan, digambarkan, dijelaskan, atau digabungkan dalam sebuah Ciptaan; dan (c) alat, benda, atau produk yang diciptakan hanya untuk menyelesaikan masalah teknis atau yang bentuknya hanya ditujukan untuk kebutuhan fungsional.

Sehingga dapat disimpulkan bahwa tidak ada larangan suatu merek yang sudah terdaftar dijadikan suatu ciptaan asalkan sudah diwujudkan dalam bentuk nyata di bidang ilmu pengetahuan, seni, dan sastra.

Kembali kepada kasus lagu "Lagi Syantik", maka tidak ada aturan mengenai kekayaan intelektual yang dilanggar oleh Yogi RPH dan Siti Badriah terkait dengan penggunaan kata
"Syantik". Walaupun seandainya, kata "Syantik" tersebut sudah didaftarkan sebagai merek suatu barang dan/atau jasa, tidak juga dapat menghalangi pihak lain untuk menggunakan merek yang sudah terdaftar sebagai judul buku, judul lagu ataupun judul puisi. Berkaitan dengan permintaan pihak Syahrini agar pihak lain mengakui jargon tersebut dipopulerkan oleh Syahrini adalah perkara lain, tetapi dari segi kekayaan intelektual tidak ada hal yang dilanggar oleh pihak Yogi RPH dan Siti Badriah. Karena memang ide dan inspirasi dalam membuat suatu ciptaan bisa datang darimana saja.

*Penulis adalah Penyidik Pegawai Negeri Sipil Kekayaan Intelektual pada Kantor Wilayah Kementerian Hukum dan HAM Sumatera Utara 